Article

\title{
Numerical Assessment of an Innovative Design of an Evacuated Tube Solar Collector Incorporated with PCM Embedded Metal Foam/Plate Fins
}

\author{
Mohamed Houcine Dhaou ${ }^{1,2}$, Sofiene Mellouli ${ }^{3, *}$, Faisal Alresheedi ${ }^{1}$ and Yassine El-Ghoul ${ }^{4}$ (D) \\ 1 Department of Physics, College of Science, Qassim University, Buraidah 51411, Saudi Arabia; \\ m.dhaou@qu.edu.sa (M.H.D.); f.alresheedi@qu.edu.sa (F.A.) \\ 2 Mechanical Engineering Department, College of Engineering, Jazan University, Jazan 45142, Saudi Arabia \\ 3 Thermal and Energy Systems Studies Laboratory (LESTE), College of Engineering, University of Monastir, \\ Monastir 5000, Tunisia \\ 4 Department of Chemistry, College of Science, Qassim University, Buraidah 51411, Saudi Arabia; \\ y.elghoul@qu.edu.sa \\ * Correspondence: smellouli@jazanu.edu.sa
}

check for

updates

Citation: Dhaou, M.H.; Mellouli, S.; Alresheedi, F.; El-Ghoul, Y. Numerical Assessment of an Innovative Design of an Evacuated Tube Solar Collector Incorporated with PCM Embedded Metal Foam/Plate Fins. Sustainability 2021, 13, 10632. https://doi.org/ $10.3390 /$ su131910632

Academic Editor:

Fatih Selimefendigil

Received: 28 August 2021

Accepted: 16 September 2021

Published: 24 September 2021

Publisher's Note: MDPI stays neutral with regard to jurisdictional claims in published maps and institutional affiliations.

Copyright: (c) 2021 by the authors. Licensee MDPI, Basel, Switzerland. This article is an open access article distributed under the terms and conditions of the Creative Commons Attribution (CC BY) license (https:/ / creativecommons.org/licenses/by/ $4.0 /)$.

\begin{abstract}
The objective of this manuscript is to study the possibility of improving the thermal performance of an Evacuated Tube Solar Collector (ETSC) with the integration of a Phase Change Material (PCM) incorporated into metallic foam and fitted with plate fins. A 2D mathematical model has been proposed. Two types of metal foams (copper and nickel) were inserted. In addition, the effect of metal foam pore size of on heat transfer was studied. The results were acquired through numerical simulations of four different cases; namely, Case 1: pure PCM, Case 2: with metal foam, Case 3: with fins and Case 4: with metal foam and fins. The evaluation procedure involved observing the total change in Heat Transfer Fluid (HTF) temperature and melted PCM fraction during a single day. The results proved that the thermal performance of ETSC is improved considerably by inserting metal foam and fins simultaneously. The time required for the whole process is improved by almost $9 \%$ compared to the case of pure PCM, and $2 \%$ compared to the case of inserting only plate fins. Results revealed that the pore size of the metal foams slightly affects the dynamic process of heat storage/release in the ETSC/PCM system.
\end{abstract}

Keywords: PCM; metal foam; evacuated solar tube

\section{Introduction}

In recent decades, global energy consumption has increased sharply. Housing is the sector that consumes the most energy. Recently, there has been a significant increase in energy demand for domestic hot water. Faced with this situation, for environmental and economic reasons, the energy systems must be efficient and self-sufficient in energy. Renewable resources can also be used in an efficient and sustainable manner when integrated with a storage energy system.

Therefore, new technologies based on the use of renewable energy as energy sources must be developed to reduce energy consumption [1]. Solar energy, which is considered to be a renewable energy, can help us reduce our dependence on other energy sources. Solar domestic hot water systems are perhaps the most commonly used solar energy device. Nevertheless, there are drawbacks to their use, such as providing sufficient hot water for a longer period of time. As a result, thermal energy storage (TES) systems are required to boost the efficiency of water heaters [2]. Phase change materials (PCMs) have aroused great interest because they store the latent heat energy in small volumes. Due to their high thermal storage density and widespread availability, PCMs are used in a wide variety of practical applications, including solar water heaters. However, these materials suffer from low thermal conductivity which reduces their performance. High porosity metal 
foams appear to be an attractive solution which can improve effective thermal conductivity without reducing storage density.

There are numerous benefits of combining a TES system with solar hot water systems. This includes efficient use of thermal energy, better system efficiency and less environmental pollution. ETSCs have one advantage over flat plate collectors (FPCs): they are easy to align with sunlight direction. Previous studies [3,4] have shown that the integration of the PCM into the ETSC allows hot water to be supplied over a long period of the day, in addition to reducing fluctuations in the water temperature output and reduce heat loss. Therefore, the application of a TES system inside an ETSC is advantageous. LHTES systems have the potential to significantly improve the performance of solar systems.

The typical concepts of integrating a PCM based storage system in a domestic solar water heater are [5]: (i) the inserting PCM capsules in the water vessel, (ii) integration of PCM inside the collector, and (iii) coupling a separate PCM unit with a conventional collector.

The PCMs can be integrated efficiently with solar water heaters to reduce heat losses at night and to improve the conservation of thermal energy [6]. Furthermore, there has been much research [6-26] conducted to investigate the effect of a finned heat pipe on the discharging process of the TES using numerical simulation methods. Results indicated that, though the energy storage capacity decreased with the immersion of the finned heat pipe, the heat transfer enhancement was more attractive. Recently, Raja et al. [26] studied an ETSC incorporating a Nano-PCM as a Latent Heat Storage System. They performed an optimization analysis of fin parameters (i.e., fin thickness and fin spacing). Their results showed that adding fins has a great effect on the phase change heat transfer of the paraffin in the ETSC. They noted that the PCM melts faster as the thickness of the fins gets thinner. Also, the addition of $1 \%$ of $\mathrm{Cu}$ to the PCM was found to be the optimum mass concentration at which the HTF outlet temperature increased by $2 \mathrm{~K}$. Moreover, from their results it was found that integrating the PCM with a Solar Parabolic Trough Reflector in the ETSC improved efficiency of the system.

Furthermore, the insertion of suitable metal foams with PCM may improve the desirable thermal properties of PCM positively. However, little is known about the effect of embedded metal foams with PCM on the thermal performance of ETSC. Furthermore, no study of an evacuated tube solar water heater embedded with PCM, metal foams, and plate fins has been published. Likewise, the energetic analysis of such systems is rarely found.

Despite many studies that have been conducted on the ETSC system integrated with PCM, none of the studies have shown the effect of integrating the ETSC system with a metal foam-PCM storage system and fins. It is also necessary to analyze the effect of foam pore size and its material type on the ETSC system. A new type of ETSC with phase change energy storage is introduced in the current study. The main objective of this study is to develop a mathematical model and to simulate an ETSC integrated with PCM incorporated into metallic foams and fitted with plate fins. Two types of metal foams (i.e., copper and nickel) are tested. Moreover, the porosity effect and the pore density of the metal foams on the thermal enhancement of the ETSC system is considered.

\section{The ETSC Configuration}

The ETSC is composed of two transparent glass tubes. In each tube there is an absorber to collect solar radiation and an exchanger to allow the transfer of thermal energy. The tubes are evacuated to prevent convective heat loss from the absorber. The inner tube serves as an absorber because the surface is treated to be absorbent and selective, meaning that it captures solar radiation. The heat is transmitted out of the vacuum casing of the tube by the circulation of a heat transfer fluid (HTF) in contact with the absorber via plate fins as shown in Figure 1. The synthetic oil is used as the heat transfer fluid (HTF) flows through the copper tube in the annular space of the ETSC. The inner glass tube is filled with PCM embedded metal foams (copper and nickel foams) in order to enhance the heat transfer. 


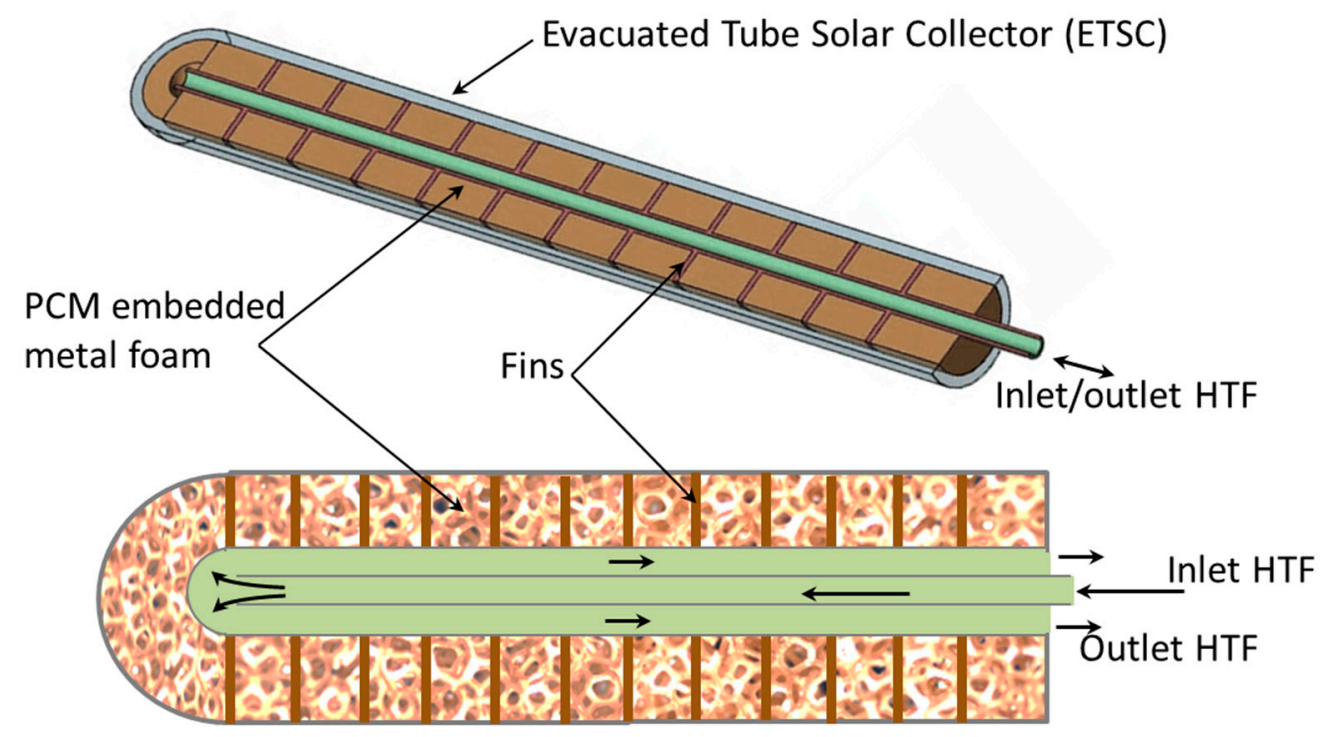

Figure 1. Cross section of ETSC incorporated with PCM embedded metal foam/plate fins.

\section{Mathematical Model}

In order to predict the heat transfer inside the ETSC incorporated with PCM embedded metal foam/plate fins, a mathematical model was developed. The following assumptions were considered [26]:

- Incompressible Newtonian fluid

- Boussinesq approximation is used

- The metal foams are homogeneous and isotropic

- Thermal resistances of wall tubes are neglected.

- Thermal equilibrium between PCM and metal foam

- $\quad$ The flow is assumed to be laminar.

- Constant thermo-physical properties of the materials

- The heat losses are constant, and the net solar radiation absorbed by the ETSC is considered to be $80 \%$ of the incident solar radiation. The ETSC system is considered to be equipped with a solar track.

\subsection{Continuity Equation}

The continuity equation is expressed as follows:

$$
\frac{\partial u}{\partial x}+\frac{\partial v}{\partial y}=0
$$

where $u$ is the $x$ component and $v$ is the $y$ component of the fluid velocity.

\subsection{Momentum equation}

The $\mathrm{x}$-momentum equation is expressed as follows:

$$
\frac{\rho_{f}}{\varepsilon} \frac{\partial u}{\partial t}+\frac{\rho_{f}}{\varepsilon^{2}}\left(u \frac{\partial(u)}{\partial x}+v \frac{\partial(u)}{\partial y}\right)=-\frac{\partial p}{\partial x}+\frac{\mu}{\varepsilon}\left(\frac{\partial^{2} u}{\partial x^{2}}+v \frac{\partial^{2} u}{\partial y^{2}}\right)-\frac{\mu}{K} u+\rho_{f} C u
$$

The y-momentum equation is expressed as follows:

$$
\frac{\rho_{f}}{\varepsilon} \frac{\partial v}{\partial t}+\frac{\rho_{f}}{\varepsilon^{2}}\left(u \frac{\partial(v)}{\partial x}+v \frac{\partial(v)}{\partial y}\right)=-\frac{\partial p}{\partial y}+\frac{\mu}{\varepsilon}\left(\frac{\partial^{2} v}{\partial x^{2}}+v \frac{\partial^{2} v}{\partial y^{2}}\right)-\frac{\mu}{K} v+\rho_{f} C v+\rho g \beta\left(T_{f}-T_{0}\right)
$$

where $\rho_{f}, p, \varepsilon, \mu, K, \beta, g, T_{f}$ and $T_{0}$ are, respectively, the density, the pressure, the porosity, the dynamic viscosity, the permeability, the thermal expansion coefficient, the gravity force, the fusion temperature of PCM and the reference temperature. 


\subsection{Energy Equations}

For the PCM-Metal foam medium

$$
\left(\rho C_{p}\right)_{e f f} \frac{\partial T}{\partial t}+\left(\rho C_{p}\right)_{l} \cdot\left(u \frac{\partial T}{\partial x}+v \frac{\partial T}{\partial y}\right)=\lambda_{e f f}\left(\frac{\partial^{2} T}{\partial x^{2}}+\frac{\partial^{2} T}{\partial y^{2}}\right)-L \frac{\partial X}{\partial t}
$$

where $\lambda_{e f f}, C p, L$ and $X$ are, respectively, the effective conductivity, the heat capacity, fusion latent heat and the melted fraction.

The effective heat capacity is calculated in terms of the porosity as follows:

$$
\left(\rho C_{p}\right)_{e f f}=\varepsilon\left[X\left(\rho C_{p}\right)_{P C M_{S}}+(1-X)\left(\rho C_{p}\right)_{P C M_{S}}\right]+(1-\varepsilon)\left(\rho C_{p}\right)_{\text {Foam }}
$$

The effective thermal conductivity is expressed as follows:

$$
\lambda_{e f f}=\varepsilon\left[X \lambda_{P C M_{l}}+(1-X) \lambda_{P C M_{S}}\right]+(1-\varepsilon) \lambda_{\text {Foam }}
$$

For the fins

$$
\left(\rho C_{p}\right)_{\text {Fins }} \frac{\partial T}{\partial t}=\lambda_{\text {Fins }}\left(\frac{\partial^{2} T}{\partial x^{2}}+\frac{\partial^{2} T}{\partial y^{2}}\right)
$$

The enthalpy of the PCM:

$$
h=h_{r e f}+\int_{T_{r e f}}^{T} C_{p} d T+X L
$$

The PCM reacted fraction $X$ is defined as follows:

$$
X=\left\{\begin{array}{ccc}
0 & \text { si } & T\left\langle T_{\text {solidus }}\right. \\
\frac{T-T_{S}}{T_{S}-T_{l}} & \text { si } & T_{\text {solidus }}\left\langleT \left\langle T_{\text {liquidus }}\right.\right. \\
1 & \text { si } & T_{\text {liquidus }}\langle T
\end{array}\right.
$$

The thermo-physical proprieties of materials are reported in Table 1.

Table 1. Thermo-physical proprieties of PCM/metal foam composites taken from [21].

\begin{tabular}{cccccccc}
\hline Properties & $\begin{array}{c}\text { Pure Paraffin } \\
\text { - }\end{array}$ & 5 PPI & $\begin{array}{c}\text { +Nickel Foam } \\
\mathbf{1 0} \text { PPI }\end{array}$ & 25 PPI & 5 PPI & $\begin{array}{c}\text { +Copper Foam } \\
\text { 10 PPI }\end{array}$ & 25 PPI \\
\hline $\begin{array}{c}\text { Melting point } \\
\quad\left({ }^{\circ} \mathrm{C}\right)\end{array}$ & 60.79 & 61.23 & 61.40 & 61.34 & 60.99 & 61.02 & 61.19 \\
$\begin{array}{c}\text { Freezing } \\
\text { point }\left({ }^{\circ} \mathrm{C}\right)\end{array}$ & 58.40 & 57.52 & 57.33 & 57.25 & 57.74 & 57.16 & 57.22 \\
$\begin{array}{c}\text { Latent Heat } \\
\quad \mathrm{kJ} / \mathrm{kg})\end{array}$ & 189.4 & 185.2 & 181.6 & 182.4 & 174.9 & 181.9 & 181.1 \\
$\begin{array}{c}\text { Thermal } \\
\text { conductivity } \\
\quad(\mathrm{W} / \mathrm{mk})\end{array}$ & 0.305 & 1.2 & 1.1 & 1.18 & 4.9 & 5.2 & 4.6 \\
$\begin{array}{c}\text { Specific Heat } \\
\mathrm{C} p(\mathrm{~kJ} / \mathrm{kgK})\end{array}$ & 1.959 & 1.695 & 1.590 & 1.648 & 1.617 & 1.533 & 1.614 \\
Porosity $\varepsilon(\%)$ & - & 92 & 91 & 93 & 94 & 93 & 92 \\
\hline
\end{tabular}

\subsection{Initial and Boundary Conditions}

Initially, the domains of the HTF, the fins and the PCM are considered at a uniform temperature of $25^{\circ} \mathrm{C}$.

For the boundary conditions, the following conditions are considered:

(i). The inter-surfaces between the different domains such as PCM, HTF, tube wall and fins inside the ETSC are defined as thermally coupled boundary conditions 
(ii). The inlet HTF tube is adjusted at a constant flow rate.

(iii). For the top wall of the ETSC, a solar heat flux is imposed via the UDF. The equation of the solar heat flux, which a result of the fitting curve, it is a polynomial of order 6 .

(iv). The external down wall is adiabatic.

\section{Numerical Method and Validation}

The problem is simulated numerically using the commercial CFD software (Ansys 14). The discrete elements for all domains of the ETSC system are produced using unstructured tetrahedral meshes. User Defined Function (UDF) was generated to calculate solar radiation. The Darcy-Brinkman model and the enthalpy-porosity formulation [22] were used to formulate a single energy equation for the flow in porous media.

The numerical model is validated with that presented by Liangdong et al. [10] as shown in Figure 2.

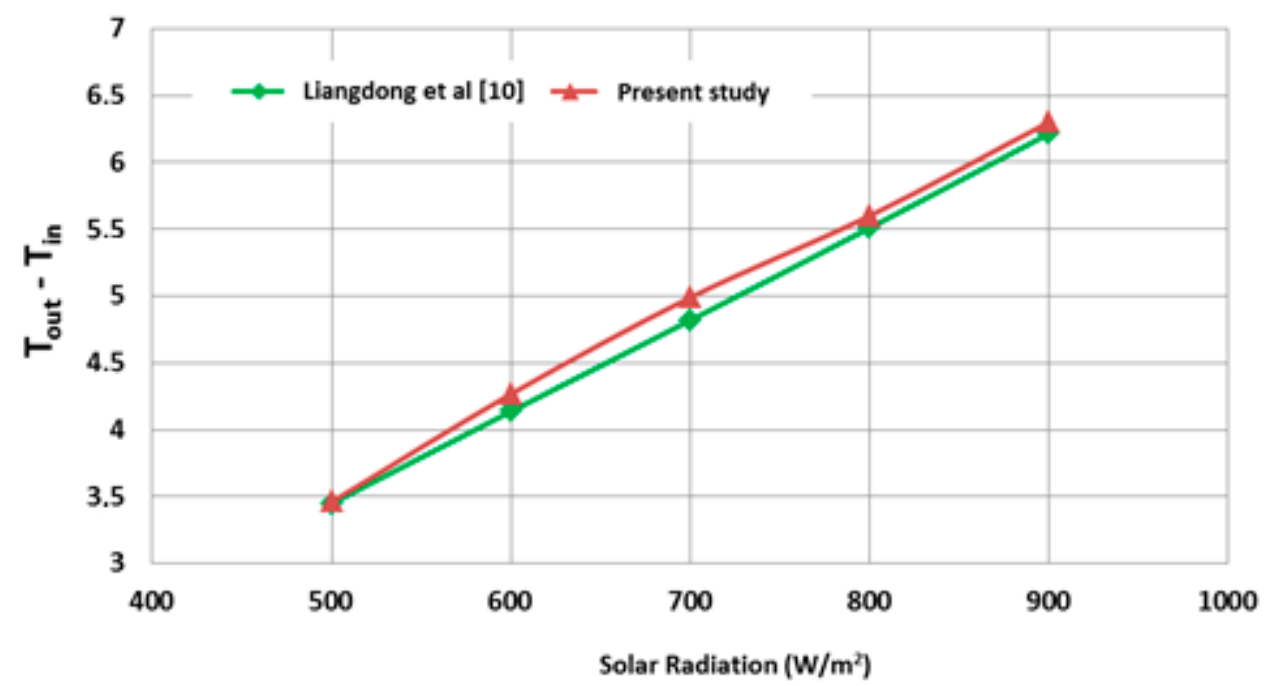

Figure 2. The validation of the mathematical model.

\section{Results and Discussions}

Figure 3 show the hourly variation of the solar heat flux incident on the evacuated tube. The similar heat flux was used and the inlet temperature of HTF is fixed at $300 \mathrm{~K}$, for all cases of simulation. Figure 4 show the contours of the temperature and the melted fraction, for three different period.

\subsection{Effect of the Thermal Conductivity Enhancer Method into the ETSC}

The effect of the enhancer method is discussed using four cases, which are: (1) pure PCM, (2) with 12 fins, (3) with metal foam and (4) with metal foam and 12 fins. Notice that the storage capacity of PCM should be the same, and consequently the geometric parameters are fixed for each case.

Figure 5 shows the HTF temperature for the four cases and Figure 6 shows the variation of the PCM melted fraction for the studied cases. The average melted PCM fraction is faster when the heat transfer enhancement method is used in the cases (3) and (4), as shown. Using case (1) as the basis, the melting rate is slightly faster by adding the plate fins in the PCM case (2), which indicates that the plate fins have reduced the PCM's thermal resistance. Besides that, in comparison to case (1), the addition of copper foam (i.e., case (3)) improves heat transfer because more heat can be extracted from the PCM and transferred to the HTF via volumetric heat exchange in the foam structure. However, when the fins are added with the copper foam (i.e., case (4)), there is no discernible difference in the rate of heat transfer. This can be explained by the fact that when the copper foam is inserted, the heat transfer rate reaches its maximum due to the HTF's thermal resistance. Thus, inserting copper foam is sufficient, and there is no need to add fins with copper foam. 


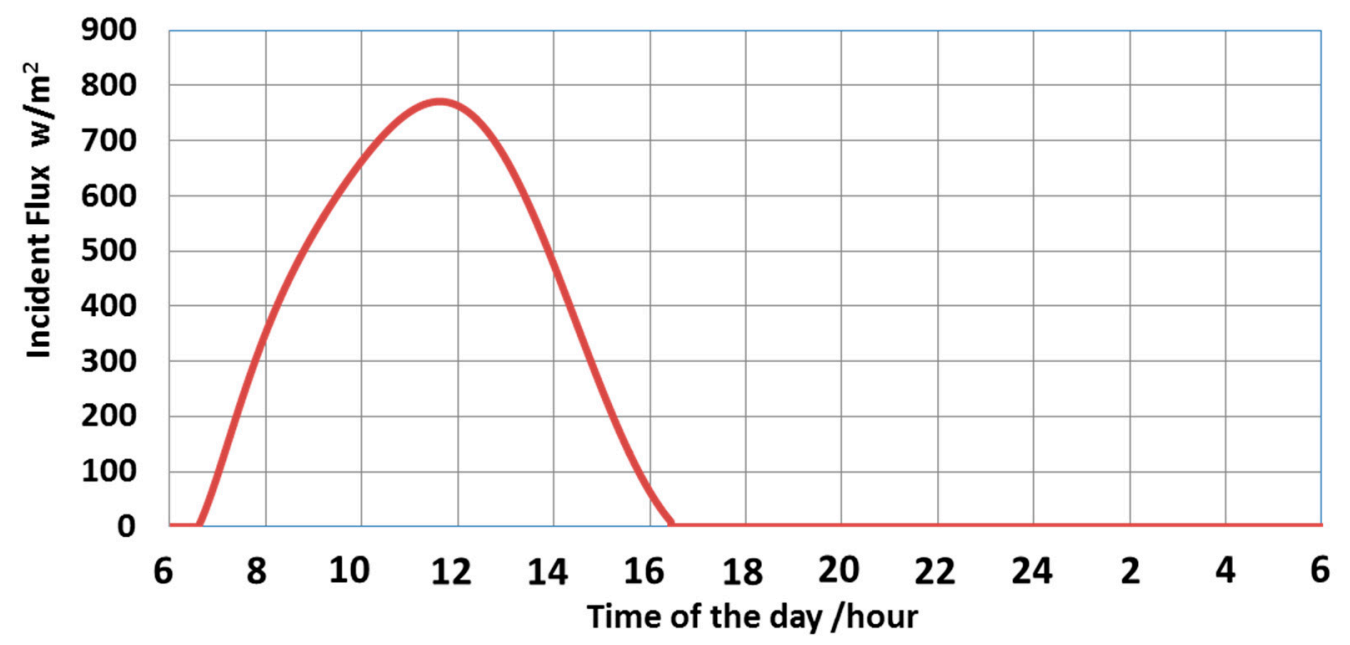

Figure 3. Evolution of the solar heat flux incident on the evacuated tube.

(a)

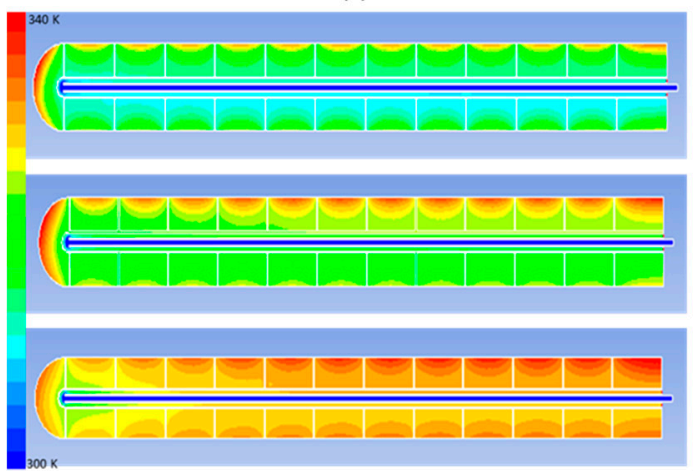

(b)

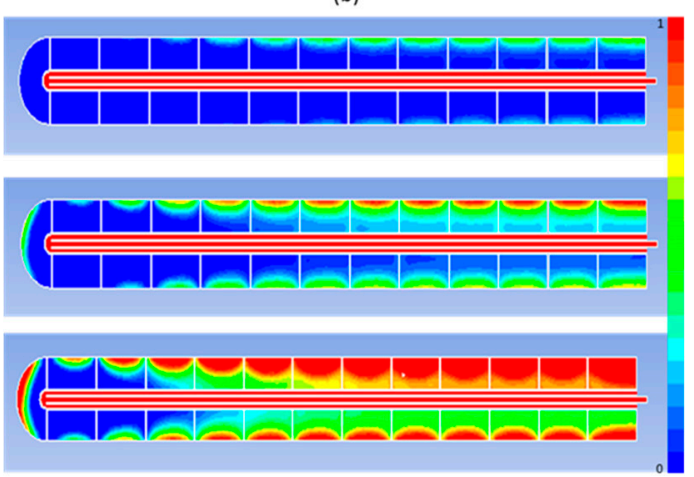

Figure 4. The contours of (a) the temperature and (b) the melted fraction, for three different period.

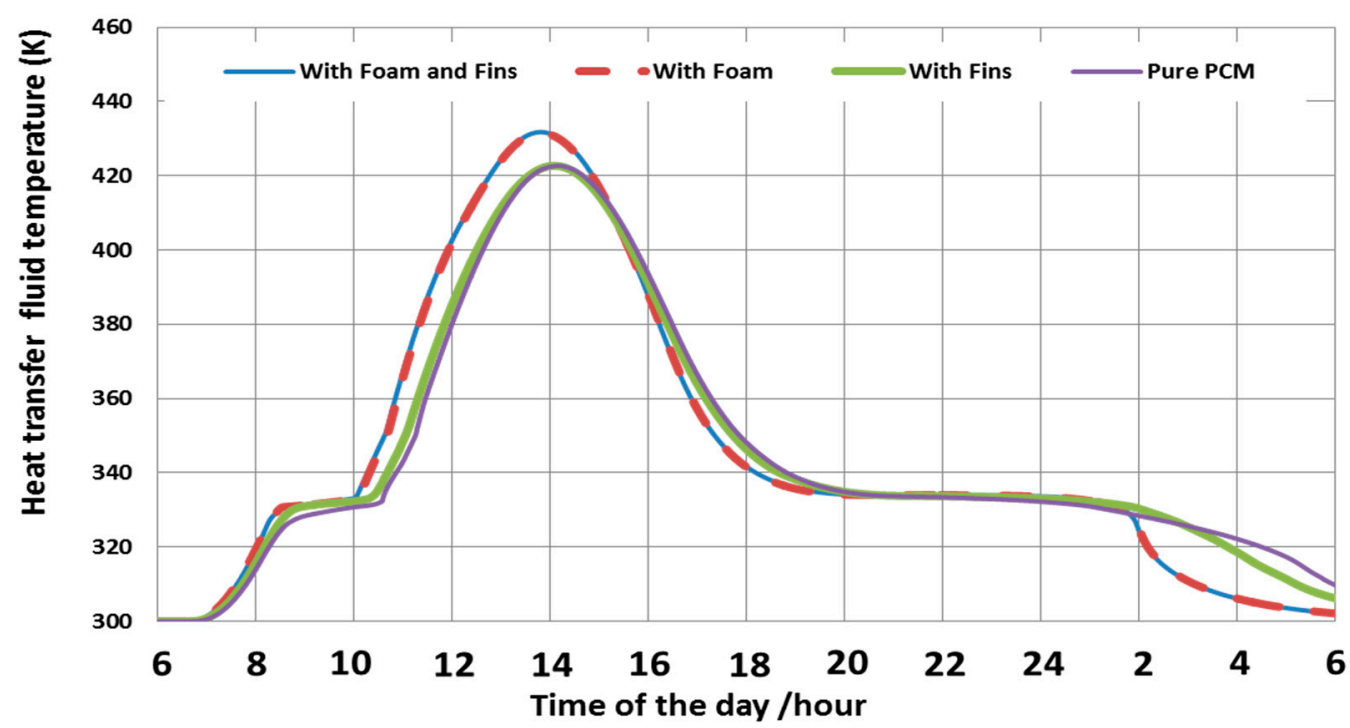

Figure 5. The HTF temperature for the four cases: Case (1): Pure PCM, Case (2): with fins, Case (3): with metal foam and Case (4): with metal foam and fins. 


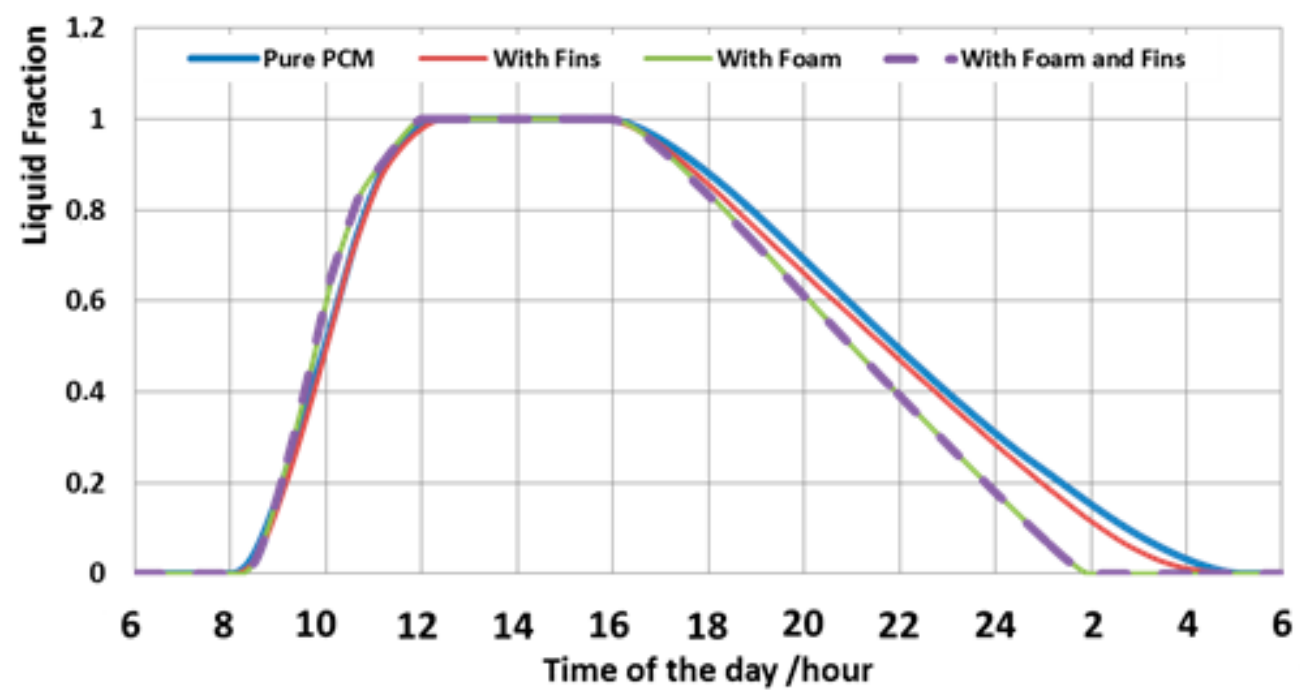

Figure 6. Time evolution of the PCM melted fraction for: Case (1): Pure PCM, Case (2): With metal foam, Case (3): with fins and Case (4): with metal foam and fins.

For the freezing process, the average melted PCM fraction is decreased faster in the cases (3) and (4). The reason for this is that by incorporating plate fins and copper foam, the heat transfer rate from the PCM to the HTF is accelerated, resulting in a decrease in PCM temperature. The metal foam improves heat transfer, bringing the PCM temperature closer to that of the HTF. As a result, the melted PCM fraction decreases relatively faster in case (4), and the HTF temperature rapidly reaches the inlet HTF temperature values compared to cases (1) and (2) as shown in Figure 5.

As illustrated in Figure 6, the change in liquid fraction changes more rapidly during the freezing process than during the melting process.

Case (4) takes the least time to load/unload, process time is apparently reduced by approximately $9 \%$ and $2 \%$, compared to case (1) and case (3), respectively, when the fins are inserted.

\subsection{Effect of the Metal Foam Type}

In order to understand the effect of the integration of metal foam inside the ETSC/PCM system, two types of base material, copper and nickel, are tested. Figure 7 shows the variation of the HTF temperature for pure PCM case and for the two cases of metal foams (i.e., copper and nickel).

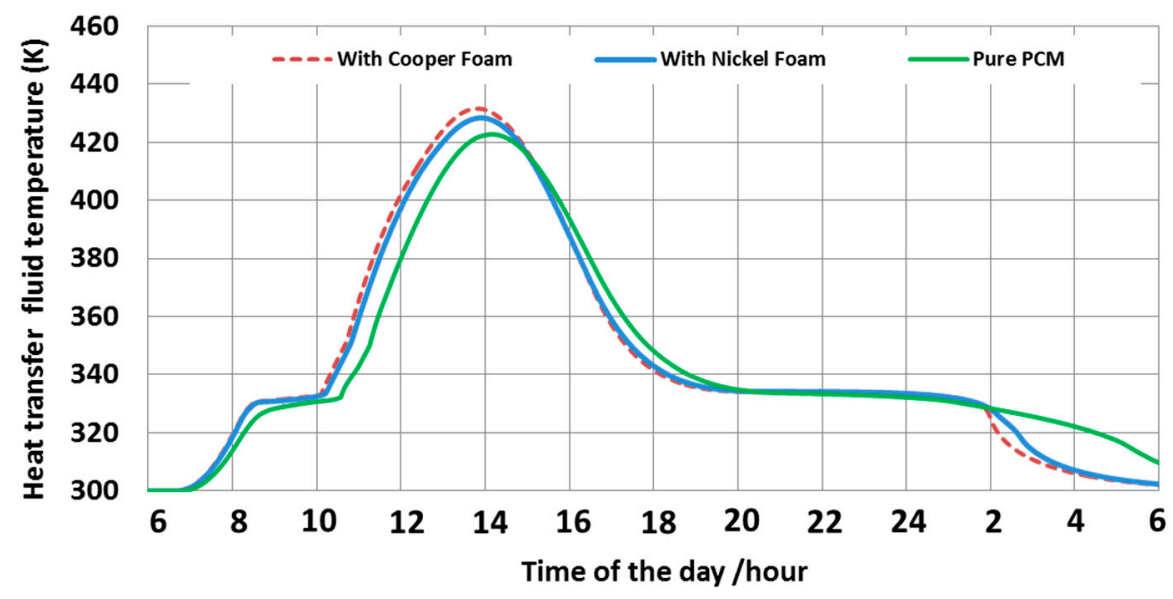

Figure 7. The HTF temperature evolution for various metal foam types. 
Figure 7 shows that the metal foam manufactured from copper yields a higher HTF temperature of $430 \mathrm{~K}$ compared those of pure $\mathrm{PCM}$, and nickel foam were $421 \mathrm{~K}$ and $425 \mathrm{~K}$, respectively. This is because the thermal conductivity of a PCM/nickel foam composite is nearly three times that of pure PCM, while the thermal conductivity of a PCM/copper foam composite is nearly 15 times that of pure PCM. Figure 8 shows that with metal foam manufactured from copper, the melting and freezing processes are faster than other cases.

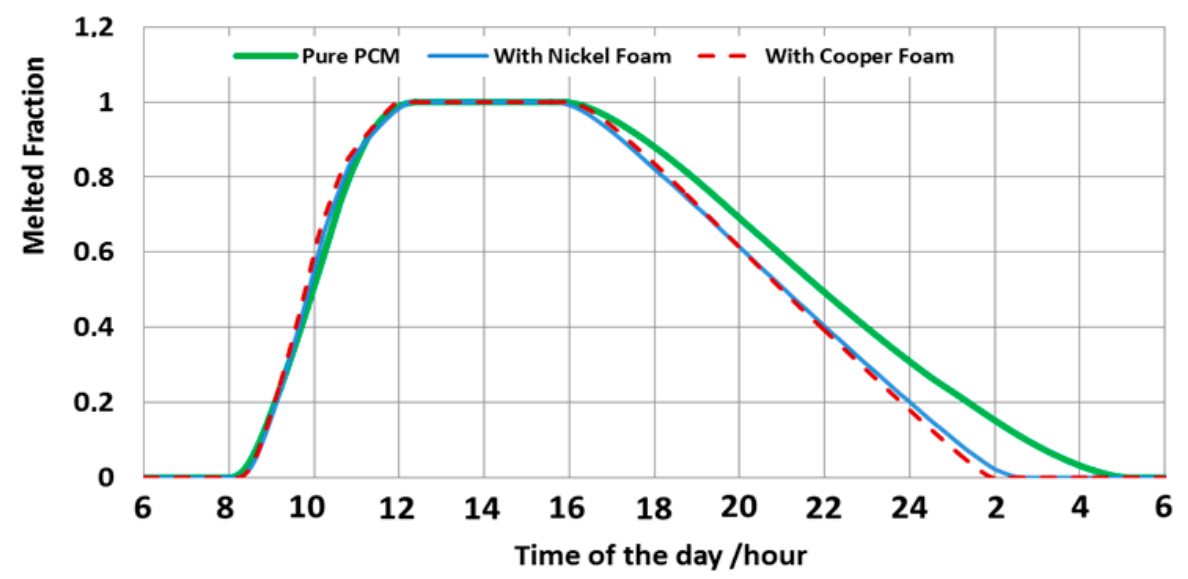

Figure 8. The PCM melted fraction evolution for various metal foam types.

\subsection{Effect of the Pore Size of the Copper Foam}

The geometric parameter which influences the performance of a metal foam exchanger is the size of the pores. As a result, three different pore sizes of copper foam were considered: 5 PPI, 10 PPI, and 25 PPI, while the other parameters, particularly the amount of PCM, remained constant. Figure 9 shows that with 5 PPI size copper foam, the melting and freezing processes are faster than with other pore sizes. By reducing the pore size, the heat transfer surface per volume increases, resulting in increased heat rates and thus improved charging/discharging performance.

\subsection{Effect of the Pore Size of the Nickel Foam}

For the case with nickel foam inserted, melted PCM fraction variation is presented in Figure 10 for the three pore sizes (i.e., 5 PPI, 10 PPI and 25 PPI). The results indicate that the melting process is slightly faster with a pore size of $10 \mathrm{PPI}$. This is explained by the lower latent heat capacity and lower PCM content of the 10 PPI nickel foam, which are a result of the metal foam's lower pore volume due to its lower porosity, as shown in Table 1. 
(a)

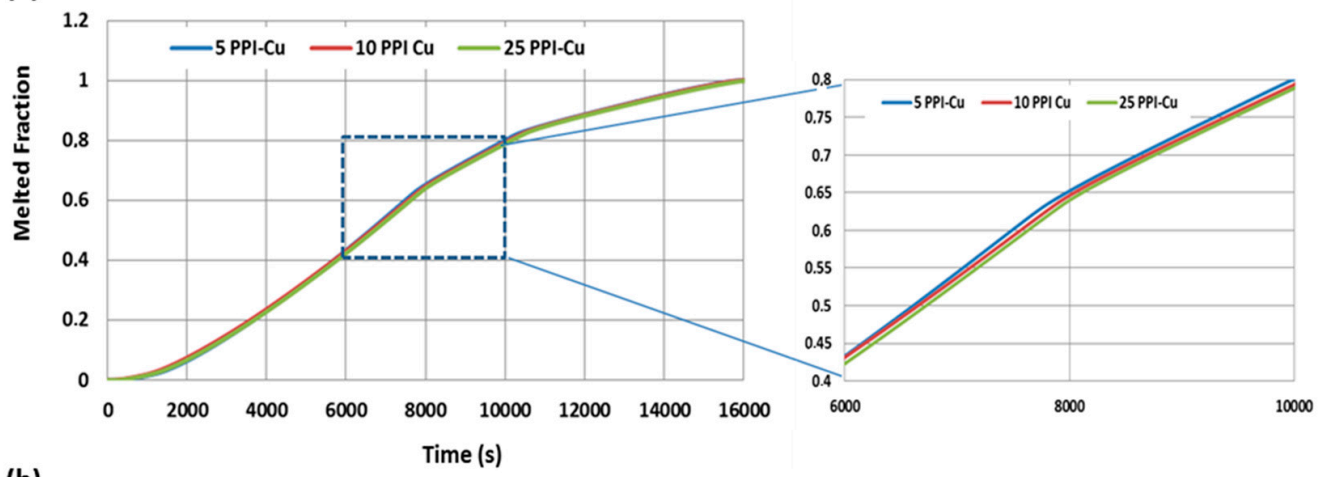

(b)

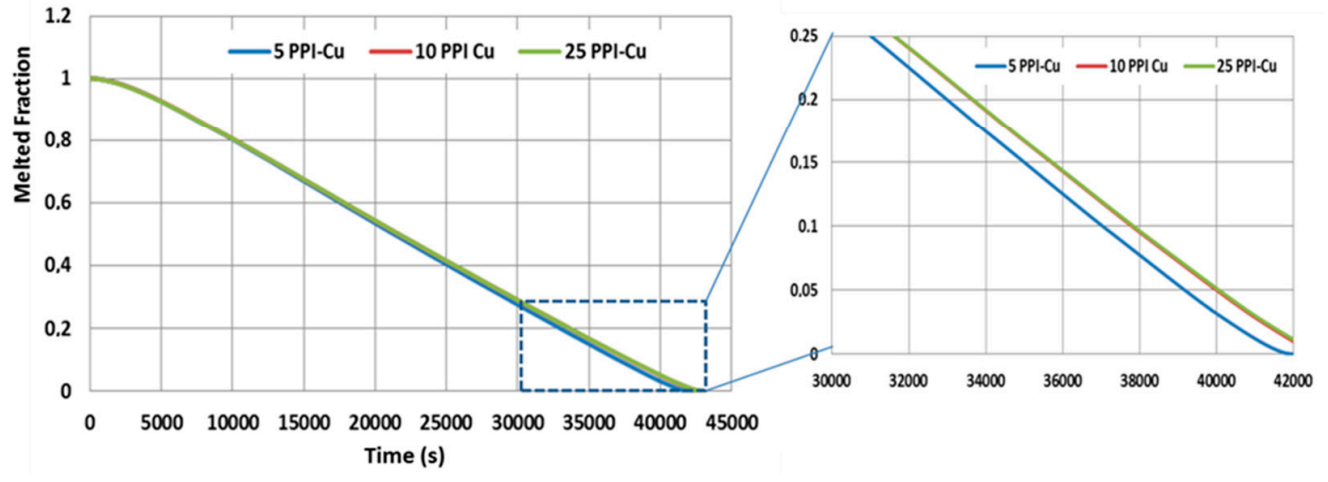

Figure 9. Time evolution of the PCM melted fraction with 5 PPI,10 PPI and 25 PPI copper foam composites in the case of (a) charging process and (b) discharging process.

(a)

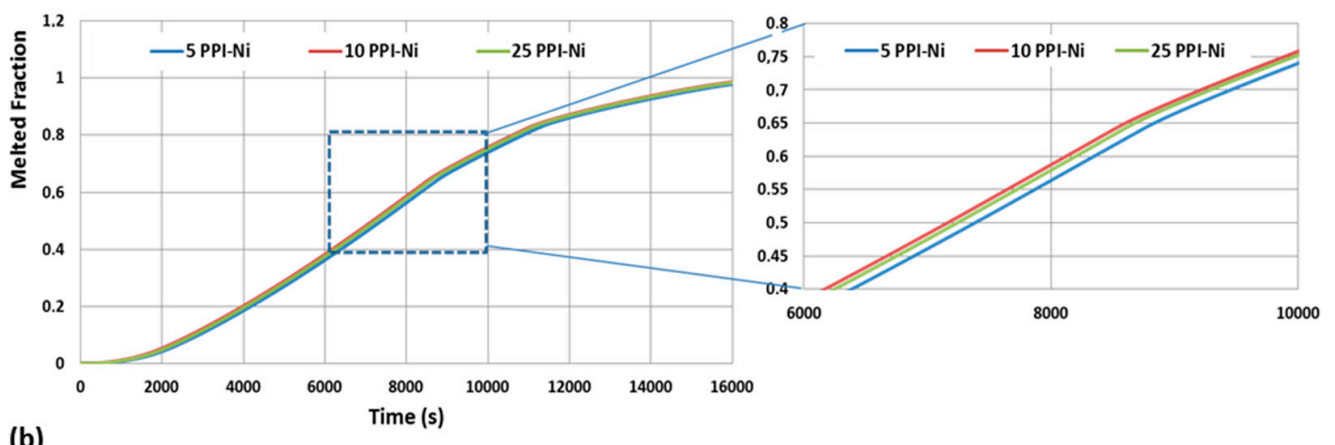

(b)

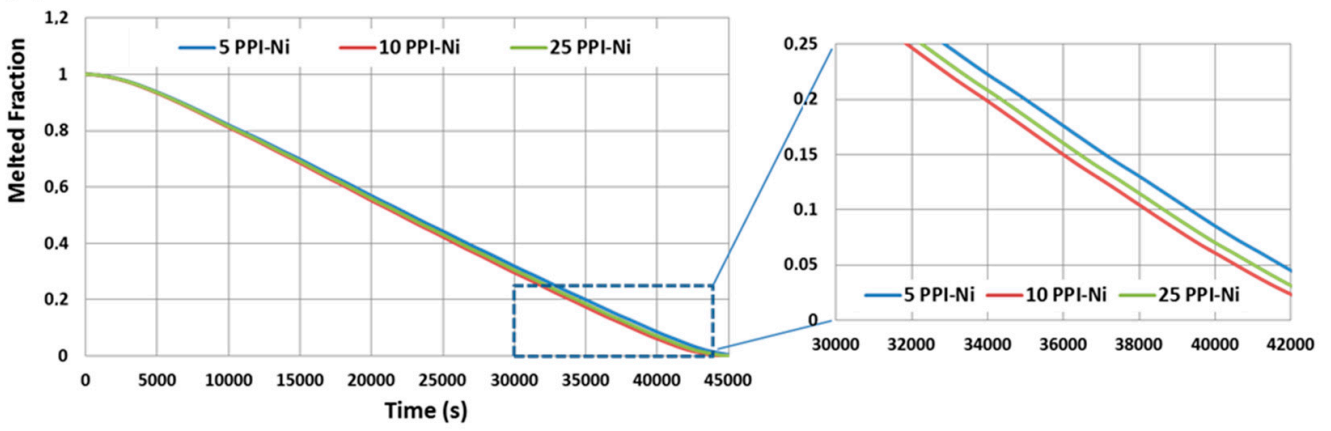

Figure 10. Time evolution of the PCM melted fraction with 5 PPI,10 PPI and 25 PPI nickel foam composites in the case of (a) charging process and (b) discharging process.

\section{Conclusions}

A two-dimensional mathematical model for an Evacuated Tube Solar Collector (ETSC) embedded PCM integrated with heat enhancers such as metal foams and fins is developed. 
Two types of metal foams (i.e., nickel and copper) are considered. The effect of the pores per inch of the metal foams were studied. The enhancement in thermal performance caused by the addition of a thermal conductivity enhancer to the ETSC is determined. The study reveals the following conclusions:

- $\quad$ The ETSC/PCM system achieved higher thermal performance by inserting copper foams. The heat storage/release process is decreased by $9 \%$ compared with the pure PCM case and $2 \%$ compared with the fins case.

- When the metal foam is inserted, the melted PCM fraction is faster in the solidification process than the melting process.

- $\quad$ The melting/freezing processes are slightly faster, with 5 PPI copper foam and 10 PPI nickel foam pore sizes, which correspond to the lower latent heat capacity and lower amount of PCM.

- $\quad$ The heat storage/release rate process enhanced for the lower foam porosity.

Author Contributions: Conceptualization, S.M. and M.H.D.; methodology, S.M.; software, F.A.; validation, S.M., F.A. and Y.E.-G.; formal analysis, F.A.; investigation, Y.E.-G.; resources, S.M.; data curation, M.H.D.; writing—original draft preparation, M.H.D.; writing—review and editing, S.M.; visualization, F.A.; supervision, Y.E.-G.; project administration, M.H.D.; funding acquisition, M.H.D. All authors have read and agreed to the published version of the manuscript.

Funding: This research was funded by Qassim University, grant number 10105-cos-2020-1-3-I.

Institutional Review Board Statement: Not applicable.

Informed Consent Statement: Not applicable.

Data Availability Statement: Not applicable.

Acknowledgments: The authors gratefully acknowledge Qassim University, represented by the Deanship of Scientific Research, on the financial support for this research under the number (10105cos-2020-1-3-I) during the academic year 1442 AH/2020 AD.

Conflicts of Interest: The authors declare no conflict of interest.

\section{References}

1. Khan, M.M.A.; Ibrahim, N.I.; Mahbubul, I.; Ali, H.M.; Saidur, R.; Al-Sulaiman, F.A. Evaluation of solar collector designs with integrated latent heat thermal energy storage: A review. Sol. Energy 2018, 166, 334-350. [CrossRef]

2. Olfian, H.; Ajarostaghi, S.S.M.; Ebrahimnataj, M. Development on evacuated tube solar collectors: A review of the last decade results of using nanofluids. Sol. Energy 2020, 211, 265-282. [CrossRef]

3. Souza, J.V.D. Conception et Optimisation d ' un Capteur Solaire Thermique Innovant Adapt é à la Rénovation é Nerg é Tique gr â ce à l' int é Gration du Stockage. Ph.D. Thesis, Université de Grenoble, Saint-Martin-d'Hères, France, 2012.

4. Algarni, S.; Mellouli, S.; Alqahtani, T.; Almutairi, K.; Anqi, A. Experimental investigation of an evacuated tube solar collector incorporating nano-enhanced PCM as a thermal booster. Appl. Therm. Eng. 2020, 180. [CrossRef]

5. Bouadila, S.; Lazaar, M.; Farhat, A. Etude expérimentale du stockage thermique par chaleur latente dans un capteur solaire sous vide Experimental study of latent heat storage in a vacuum solar collector. In Proceedings of the 13éme Congrès de la Société Française de Génie des Procédés SFGP, Paris, France, 29 November-1 December 2011; pp. 1-6.

6. Elarem, R.; Alqahtani, T.; Mellouli, S.; Askri, F.; Edacherian, A.; Vineet, T.; Badruddin, I.A.; Abdelmajid, J. A comprehensive review of heat transfer intensification methods for latent heat storage units. Energy Storage 2020, 19, e127. [CrossRef]

7. Laghzaoui, A.; Peerhossaini, D. Stockage De Chaleur: Energy Solaire Et Autres Applications. Étude Bibliogr. Ec. Mines Douai 2013, $1-54$.

8. Yang, X.; Wang, W.; Yang, C.; Jin, L.; Lu, T.J. Solidification of fluid saturated in open-cell metallic foams with graded morphologies. Int. J. Heat Mass Transf. 2016, 98, 60-69. [CrossRef]

9. Javadi, F.; Saidur, R.; Kamalisarvestani, M. Investigating performance improvement of solar collectors by using nanofluids. Renew. Sustain. Energy Rev. 2013, 28, 232-245. [CrossRef]

10. Ma, L.; Zhao, T.; Zhang, J.; Zhao, D. Numerical study on the heat transfer characteristics of filled-type solar collector with U-tube. Appl. Therm. Eng. 2016, 107, 642-652. [CrossRef]

11. Zheng, L.; Zhang, W.; Xie, L.; Wang, W.; Tian, H.; Chen, M. Experimental study on the thermal performance of solar air conditioning system with MEPCM cooling storage. Int. J. Low Carbon Technol. 2019, 14, 83-88. [CrossRef]

12. Zhang, P.; Meng, Z.; Zhu, H.; Wang, Y.; Peng, S. Experimental and Numerical Study of Heat Transfer Characteristics of a Paraffin/Metal Foam Composite PCM. Energy Procedia 2015, 75, 3091-3097. [CrossRef] 
13. Kumar, P.M.; Mylsamy, K. Experimental investigation of solar water heater integrated with a nanocomposite phase change material. J. Therm. Anal. Calorim. 2019, 136, 121-132. [CrossRef]

14. Chen, X.; Li, X.-L.; Xia, X.; Sun, C.; Liu, R. Thermal Performance of a PCM-Based Thermal Energy Storage with Metal Foam Enhancement. Energies 2019, 12, 3275. [CrossRef]

15. Mahfuz, M.; Anisur, M.; Kibria, M.; Saidur, R.; Metselaar, H.S.C. Performance investigation of thermal energy storage system with Phase Change Material (PCM) for solar water heating application. Int. Commun. Heat Mass Transf. 2014, 57, 132-139. [CrossRef]

16. El Idi, M.M.; Karkri, M. Heating and cooling conditions effects on the kinetic of phase change of PCM embedded in metal foam. Case Stud. Therm. Eng. 2020, 21, 100716. [CrossRef]

17. Boussaba, L.; Foufa, A.; Makhlouf, S.; Lefebvre, G.; Royon, L. Elaboration and properties of a composite bio-based PCM for an application in building envelopes. Constr. Build. Mater. 2018, 185, 156-165. [CrossRef]

18. Fteiti, M.; Alaidrous, A. Latent Heat Storage During Melting and Solidification of a Phase Change Material ( PCM ) Embedded with a Porous Matrix of High Thermal Conductivity. Int. J. Energy Eng. 2020, 10, 1-9. [CrossRef]

19. Srivatsa, P.V.S.S.; Baby, R.; Balaji, C. Numerical Investigation of PCM Based Heat Sinks with Embedded Metal Foam/Crossed Plate Fins. Numer. Heat Transf. Part A Appl. 2014, 66, 1131-1153. [CrossRef]

20. Sweidan, A.H.; Heider, Y.; Markert, B. Modeling of PCM-based enhanced latent heat storage systems using a phase-field-porous media approach. Contin. Mech. Thermodyn. 2020, 32, 861-882. [CrossRef]

21. Xiao, X.; Zhang, P.; Li, M. Preparation and thermal characterization of paraffin/metal foam composite phase change material. Appl. Energy 2013, 112, 1357-1366. [CrossRef]

22. Brent, A.D.; Voller, V.R.; Reid, K.J. “Enthalpy-porosity technique for modelling convection -diffusion phase change application to the melting of pure metal". Num. Heat Transf. 1988, 13, 297-318.

23. Tiari, S.; Qiu, S.; Mahdavi, M. Discharging process of a finned heat pipe-assisted thermal energy storage system with high temperature phase change material. Energy Convers. Manag. 2016, 118, 426-437. [CrossRef]

24. Lohrasbi, S.; Miry, S.Z.; Gorji-Bandpy, M.; Ganji, D.D. Performance enhancement of finned heat pipe assisted latent heat thermal energy storage system in the presence of nano-enhanced $\mathrm{H}_{2} \mathrm{O}$ as phase change material. Int. J. Hydrogen Energy 2017, 42, 6526-6546. [CrossRef]

25. Tiari, S.; Qiu, S.; Mahdavi, M. Numerical study of finned heat pipe-assisted thermal energy storage system with high temper-ature phase change material. Energy Convers. Manag. 2015, 89, 833-842. [CrossRef]

26. Raja, E.; Talal, A.; Sofiene, M.; Aich, W.; Kheder, N.; Kolsi, L.; Jemni, A. Numerical Study of an Evacuated Tube Solar Collector Incorporating a Nano-PCM as a Latent Heat Storage System. Case Stud. Therm. Eng. 2021, 24, 100859. 